\title{
Nutritional Composition of Soft Drinks and Chips Consumed by School-aged Children in Dakar (Senegal)
}

\author{
Amadou Diop ${ }^{1, ~ *, ~ D i o k e l ~ S a r r ~}{ }^{1,2}$, Ndèye Yacine Ndiaye Diallo², Nassifatou Koko Tittikpina ${ }^{3}$, \\ Ousmane Niass ${ }^{1}$, Serigne Omar Sarr ${ }^{1}$, Bara Ndiaye ${ }^{1}$, Yerim Mbagnick Diop ${ }^{1}$ \\ ${ }^{1}$ Department of Pharmacy, Faculty of Medicine, Pharmacy and Odontology, Cheikh Anta DIOP University, Dakar, Senegal \\ ${ }^{2}$ Food Technology Institute, Ministry of Industrial Development, Dakar, Senegal \\ ${ }^{3}$ Department of Pharmaceutical Sciences, Faculty of Health Sciences, University of Lomé, Lomé, Togo
}

Email address:

amadou4.diop@ucad.edu.sn (A. Diop)

${ }^{*}$ Corresponding author

\section{To cite this article:}

Amadou Diop, Diokel Sarr, Ndèye Yacine Ndiaye Diallo, Nassifatou Koko Tittikpina, Ousmane Niass, Serigne Omar Sarr, Bara Ndiaye, Yerim Mbagnick Diop. Nutritional Composition of Soft Drinks and Chips Consumed by School-aged Children in Dakar (Senegal). Science Journal of Analytical Chemistry. Vol. 9, No. 2, 2021, pp. 50-57. doi: 10.11648/j.sjac.20210902.13

Received: May 19, 2021; Accepted: June 1, 2021; Published: June 10, 2021

\begin{abstract}
In Senegal, social-economic changes have likely affected dietary habits. As in many parts of the world, Senegalese children consume significant amounts of food between main meals (snacking) with a wide consumption of soft drinks and chips products which can have negative effects on children sanitary health. This study aims at investigating some dietary habits of Senegalese school-age children and the nutritional composition of some snacking products to alleviate nutrition and health issues caused by food quality. A survey was carried out in schools in some districts of Dakar and allowed to identify the most consumed soft drinks and chips from which samples were taken and subjected to physicochemical analysis. Snacking was a common habit in Senegalese school-age children with $68 \%$ declaring regular consumption of chips and $88 \%$ that of sweetened drinks. The main component in soft drinks after water was carbohydrates with contents ranging between 6.50 \pm 0.27 and $13.75 \pm 0.01 \%$ and energy values varying between $26.00 \pm 1.09$ and $54.99 \pm 0.04 \mathrm{kcal} / 100 \mathrm{~g}$. Some minerals such as magnesium, sodium, potassium and calcium were also present with levels comprised between $4.35 \pm 0.15 \mathrm{mg} / 100 \mathrm{~g}$ to $167.41 \pm$ $9.50 \mathrm{mg} / 100 \mathrm{~g}$. The ranges were: $\mathrm{Mg}(8.26 \pm 0.23-12.11 \pm 0.84), \mathrm{Na}(4.35 \pm 0.15-8.18 \pm 0.10), \mathrm{K}(4.50 \pm 0.35-8.18 \pm 0.52)$ and $\mathrm{Ca}(120.51 \pm 10.90-167.41 \pm 9.50)$. The macronutrients in chips were proteins $(5.95 \pm 0.10-10.70 \pm 0.05 \%)$, fat $(19.86 \pm 0.65$ - $35.94 \pm 0.01 \%)$, carbohydrates $(47.43 \pm 0.44-64.65 \pm 0.78 \%)$ and dietary fiber $(1.55 \pm 0.10-2.13 \pm 0.23 \%)$. Sodium and potassium were also present with levels of $580.04 \pm 23.98$ to $692.97 \pm 40.78 \mathrm{mg} / 100 \mathrm{~g}$ for sodium and $159.84 \pm 6.86$ to 318.57 $\pm 1.09 \mathrm{mg} / 100 \mathrm{~g}$ for potassium. The results of this study can help orient the strategies to put into effect in order to inform children and their parents on the best diets to adopt for a healthy and quality life.
\end{abstract}

Keywords: Children, School, Soft Drinks, Chips, Nutritional Components, Dakar

\section{Introduction}

Malnutrition refers to deficiencies, excesses or imbalances in a person's intake of energy and/or nutrients and includes undernutrition and overnutrition as well as micronutrient deficiencies [1-4]. It is becoming a worldwide problem affecting all countries. A recent report for the World Committee on Food Security argued that malnutrition in all its form, is a critical challenge not only in the developing but also in the developed countries. Millions of people are suffering from different forms of malnutrition. According to the WHO, 1.9 billion adults are overweight or obese while 462 million are underweight. Also, 52 million of children under-fives are suffering from wasting and approximately $45 \%$ of deaths in this category are related to undernutrition. They, often, occur in developing countries where at the same time, rates of childhood overweight and obesity are rising [5]. In Senegal, a West African country, the prevalence of malnutrition are alarmingly high among children; $17 \%$ of those under 5 years are suffering from stunting, 14\% from underweight and $7 \%$ 
from wasting. Low birth weight (less than $2.5 \mathrm{~kg}$ ) (of children whose birth weights are known) and anemia affect 16 and $66 \%$ of children under 5 years, respectively [6]. Senegal is, among other developing countries, experiencing the double burden of malnutrition, with high prevalence of both undernutrition and overweight/obesity. According a new report published in the Lancet, more than one in three low-and-middle-income countries are facing both extreme obesity and undernutrition particularly in sub-Saharan Africa, south Asia, east Asia and the Pacific [7]. A study, conducted by Faye et al. in few schools in Dakar (capital of Senegal), revealed that child and teenage obesity is a reality with a prevalence of $9.34 \%$ among 2,356 students tested [8].

Malnutrition has many adverse consequences for child survival and long-term well-being. In Senegal for example, the under-five mortality rate of about 45.3 deaths per 1,000 live births, is directly or indirectly related to micronutrient deficiencies [6]. Malnutrition weakens every part of the immune system and increases the risk of infection and infectious disease. For instance, the onset of active tuberculosis is aggravated mainly due to malnutrition [1,9]. Owing to the downward spiral of malnutrition which results in lower energy and impaired function of the brain, victims are less able to perform the tasks they need in order to acquire food, earn an income, or gain an education. It has farreaching consequences for human capital, economic productivity, and national development overall.

The common causes of malnutrition include food insecurity, lack of food, high food prices, food wastage, inefficient food processing strategies, lack of breastfeeding, psychological problems, digestive complaints and stomach conditions, etc., $[3,10]$. Some others associated increases in overweight with changes in the global food system that make less nutritious food cheaper and more accessible. Cheap food with high content of fat, sugar, and salt is very common in a lot of developing countries like Senegal. Sales of nonessential foods and beverages, as well as junk foods and sugar sweetened beverages, are on the rise in low-andmiddle-income countries (Chile, South Africa, the Philippines, Malaysia) [7, 11].

So the implementation of policies that improve diet quality and address both undernutrition and overnutrition is needed. They include adopting economic tools to limit the amount of poor quality food on the market, such as sugar taxes on sugar-sweetened-beverages. Strategies imply also to evaluate the physicochemical and nutritional quality of food. Chips and sweetened drinks are food products, highly consumed by Senegalese children and whose quality may affect children's health [12]. Also to be competitive, some manufacturers use all means to make their products appealing to children, including adding prohibited substances and making poor quality products. Unfortunately, in Senegal, no data are available on the quality of sugar-sweetened-beverages and chips. Therefore, this study aims to provide data on the nutritional and physicochemical properties of soft drinks and chips consumed by Senegalese school-age children.

\section{Material and Methods}

\subsection{Survey}

A field survey was carried out in schools in some districts of Dakar, the Senegalese capital, which concentrates $25 \%$ of the whole country's population and, consequently, the highest school population. Firstly, three districts (Maristes, Gueule Tapée and HLM), were selected on the basis of several criteria (number of schools, school population, geographical situation, and distance between districts...). Secondarily, schools in these districts were chosen according their school population, their geographical accessibility, and their acceptance to participate to the survey. Finally students aged 7-16, which were considered able to correctly answer to the questions, were randomly selected and interviewed. Informed consent has been, previously, obtained from parents' association, school administration and academic authorities before starting the survey. A survey questionnaire was developed and validated by a pre-test on a sample of 10 students to assess its comprehension and acceptability. This latter was administered to selected students during individual interviews of about 10 minutes. The collected data refer to student's age, types of products consumed, and consumption frequency.

\subsection{Sampling}

Samples of the three most-cited brands of sweetenedbeverages and chips, on the basis of the survey results, were purchased from shops and mini markets of the selected districts. For each sample of chips, six packets were collected and their contents mixed to give a composite sample representative of the brand in the considered district. Sweetened-beverage samples in a district were obtained by purchasing two beverage bottles or sachets of each brand in each district. The mixing of the bottles contents, done before analysis at the laboratory, results in the composite sample from which a final sample is taken. Therefore, three samples of sweetened-beverages and three of chips were collected in each district giving a total of nine samples for each product.

\subsection{Chemicals and Reagents}

All the chemicals and solvents of technical or analytical grades were purchased from local suppliers (Technologies services, Fermon Labo Sénégal and Bouattour Equipements Services, Dakar, Senegal). Double distilled water and Class A borosilicate volumetric glassware were used for analysis.

\subsection{Physicochemical Determination}

\subsubsection{Drinks}

\section{(i) Total Sugars}

Total sugars were determined using the Luff-Schoorl method described by Marrubini et al. [13] according which $3 \mathrm{~g}$ of beverage sample, exactly weighed, were transferred to an Erlenmeyer flask, additionned with $50 \mathrm{ml}$ of distilled water and subjected to water bath at $60^{\circ} \mathrm{C}$ during $15 \mathrm{~min}$. After cooling, the solution was transferred into a $100 \mathrm{ml}$ volumetric flask and adjusted to volume with distilled water and filtered. 
$5 \mathrm{ml}$ of $\mathrm{HCl} 37 \%$ were added to $20 \mathrm{ml}$ of filtrate in a $50 \mathrm{ml}$ volumetric flask and subjected to water bath at $60-70^{\circ} \mathrm{C}$ during $15 \mathrm{~min}$. The obtained solution was cooled and neutralized with $40 \%$ sodium hydroxide and few drops of phenolphthalein. Then, it was decolorized using $0.1 \mathrm{~N} \mathrm{HCl}$, adjusted to volume and filtered. $5 \mathrm{ml}$ each of filtrate and Luff-Schoorl reagent were put in a round-bottomed flash to which a condenser was adapted. The mixture was heated at $60-70^{\circ} \mathrm{C}$ for $5 \mathrm{~min}$, cooled and additionned with $3 \mathrm{ml}$ each of $30 \% \mathrm{KI}$ and $6 \mathrm{~N} \mathrm{H}_{2} \mathrm{SO}_{4}$. Titration of this solution was done with $0.1 \mathrm{~N}$ sodium thiosulfate with few drops of starch as indicator. A blank solution containing $5 \mathrm{ml}$ each of distilled water and LuffSchoorl reagent was prepared and treated as the sample.

\section{(ii) Energy Value}

Energy value was calculated using the Atwater method described by Charrondiere et al. [14]. Since, there was no or very low content of fat and protein in beverages, only the contribution of carbohydrates $(4 \mathrm{kcal} / \mathrm{g})$ was considered.

\section{(iii) $\mathrm{pH}$}

It was determined using a Crison $\mathrm{pH}$-meter calibrated with buffer solutions at $\mathrm{pH} 4$ and 7. After each measurement, the $\mathrm{pH}$-meter was well rinsed and immersed in a storage solution (saturated potassium chloride) (Crison, 2004).

\section{(iv) Minerals}

$1 \mathrm{~g}$ of exactly weighed sample was dried at $100{ }^{\circ} \mathrm{C}$ and mineralized by calcination at $550{ }^{\circ} \mathrm{C}$ during two hours after which crucible containing ash was cooled. $4 \mathrm{ml}$ of nitric acid were added and evaporated to dryness and calcination was continued until grayish-white ash is obtained. The residue was dissolved in $10 \mathrm{ml}$ hydrochloric acid, filtered in a $50 \mathrm{ml}$ dilution tube and adjusted to volume with distilled water. A blank solution of distilled water was prepared and treated as the sample. Blank and sample solutions were analyzed by flame atomic absorption spectroscopy (AAnalyst 700, Perkin Elmer, USA) according the AOAC method [15]. Determinations were done in triplicate using individual standard solutions of $1000 \mathrm{ppm}$. Calibration curves were constructed by measuring the absorbance of a series of five standard solutions for each mineral and plotting absorbance (y) versus mineral concentration $(x)$. The amount of mineral was calculated based on the following regression equations: Mg: $y=0.02831 x-0.00015$; Ca: $y=0.18188 x-0.00009$; Na: $y=0.61116 x-0.00027 ; \mathrm{K}: y=0.03356 x-0.00017$. The correlation coefficients ranged from 0.991 to 0.999 .

\subsubsection{Chips}

\section{(i) Moisture and Ash Contents}

The determination of moisture and ash contents was achieved using the AOAC (Association of Official Analytical Chemists) methods 925.10 and 923.03 respectively [16, 17].

\section{(ii) Macronutrient Content}

Protein, fat and dietary fiber contents of chips were evaluated using, respectively, the following AOAC methods: 2001.11, 2003.06, $978.10[18,19,20]$. The carbohydrate content was calculated by the formula described by Charrondiere et al. [14]: $100-[\%$ protein $+\%$ fat $+\%$ water $+\%$ ash $+\%$ dietary fiber $]$. All determinations were done in triplicate.

\section{(iii) Energy Value and Mineral Content}

The energy value and mineral content were determined using the same methods as for drinks $[14,15]$.

\section{(iv) Statistical Analyses}

The statistical analysis was performed using the statistical function of Microsoft Office Excel. For each sample, three determinations have done $(n=3$, where $n$ is the number of the replications). The data were presented as mean values \pm standard deviation (SD).

\section{Results}

\subsection{Survey}

Out of 1212 students from 14 schools, 68\% (821) declared consumption of chips and $88 \%$ (1063) that of sweetened drinks. The most popular drink brands were Top Orange, Minute Maid and Tampico with respective citation frequencies of 25, 19 and 10\% (Figure 1). The most popular brands of chips were Choupa chips (32\%), Balla Gaye (21\%) and Sama done (20\%) (Figure 2).

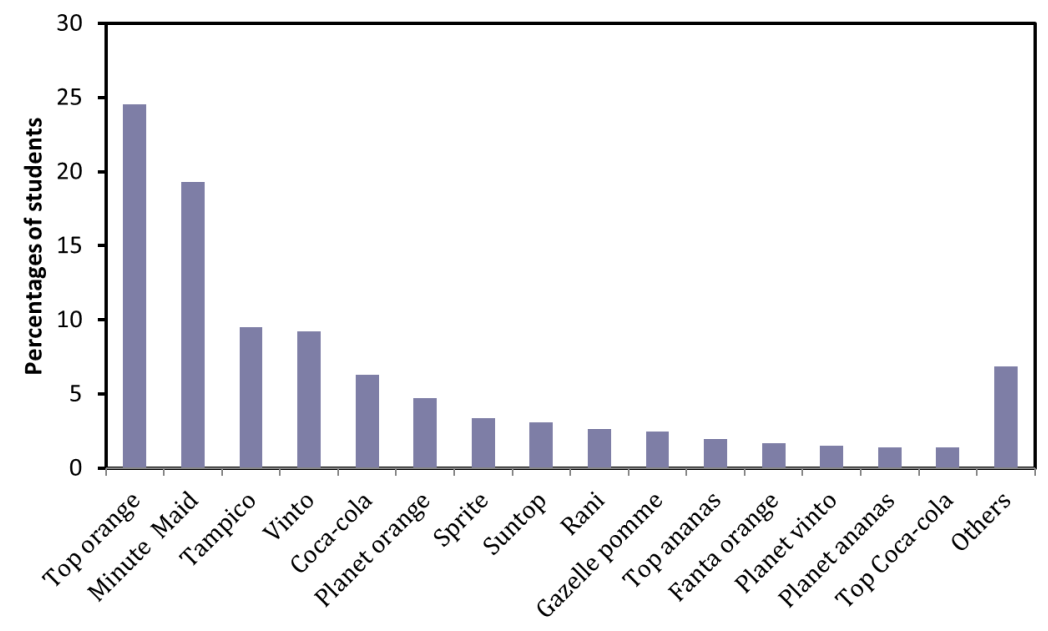

Figure 1. Most popular sweetened drink brands according school-age students of Senegal. 


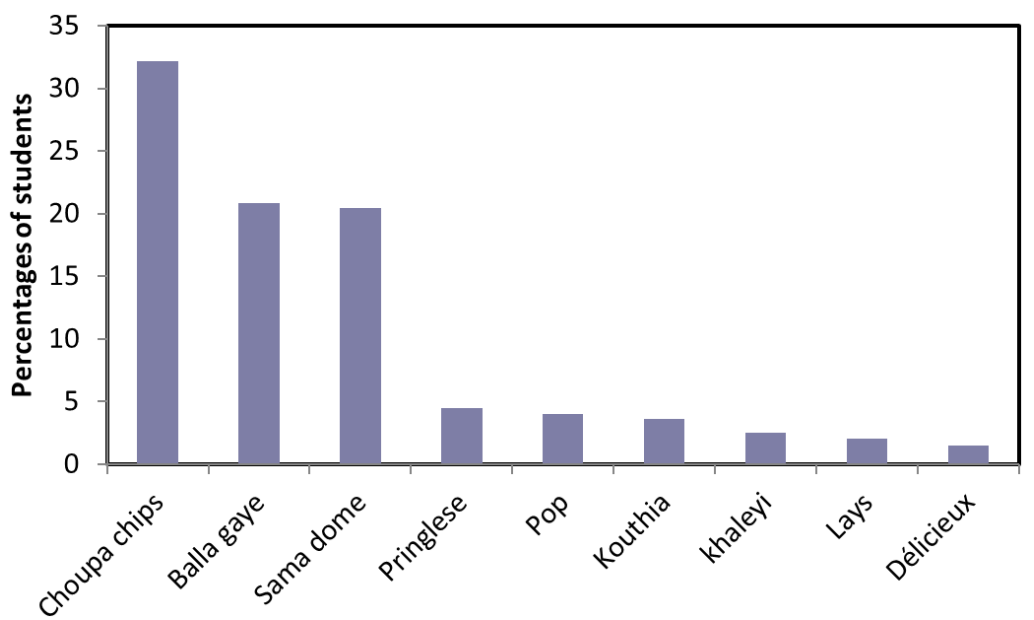

Figure 1. Most popular chips according school-age students of Senegal.

\subsection{Analysis}

\subsubsection{Drinks}

The nutritional composition and physicochemical properties of soft drink samples varied from one brand to another but were relatively similar in a sampling area for a given brand (Table 1). The total sugar contents ranged between $6.50 \pm 0.27$ and $13.75 \pm 0.01 \%$ and the energy values were between $26.00 \pm 1.09$ and $54.99 \pm 0.04$ $\mathrm{kcal} / 100 \mathrm{~g}$. Different values of total sugar and energy were recorded according to the brand; however they were relatively close for a brand when samples were collected from different areas (Table 1). The analysis results indicated the presence of minerals such as magnesium, sodium, potassium and calcium with this latter being the most predominant mineral in the sample drinks. Values of mineral contents varied between $4.35 \pm 0.15 \mathrm{mg} / 100 \mathrm{~g}$ for sodium to $167.41 \pm 9.50 \mathrm{mg} / 100 \mathrm{~g}$ for calcium. The ranges were: $\mathrm{Mg}$ $(8.26 \pm 0.23-12.11 \pm 0.84), \mathrm{Na}(4.35 \pm 0.15-8.18 \pm 0.10), \mathrm{K}$ $(4.50 \pm 0.35-8.18 \pm 0.52)$ and $\mathrm{Ca}(120.51 \pm 10.90-167.41 \pm$ 9.50). A slight difference in mineral contents according to brand and sampling area was registered (Table 2). The $\mathrm{pH}$ values of soft drink samples were relatively close and ranged between 2.79 to 3.34 (Table 1 ).

Table 1. Drink samples analysis results.

\begin{tabular}{|c|c|c|c|c|c|c|c|}
\hline Code $^{*}$ & $\begin{array}{l}\text { Total Sugars } \\
(\%)\end{array}$ & $\begin{array}{l}\text { Energy value } \\
\text { (Kcal/100g) }\end{array}$ & $\mathbf{p H}$ & $\begin{array}{l}\text { Magnesium } \\
(\mathrm{mg} / \mathbf{1 0 0})\end{array}$ & $\begin{array}{l}\begin{array}{l}\text { Sodium } \\
(\mathrm{mg} / 100)\end{array} \\
\end{array}$ & $\begin{array}{l}\text { Potassium } \\
(\mathrm{mg} / 100)\end{array}$ & $\begin{array}{l}\text { Calcium } \\
(\mathrm{mg} / \mathbf{1 0 0})\end{array}$ \\
\hline Z1-TP & $6,72 \pm 0,62$ & $26,89 \pm 2,48$ & 2,79 & $8,26 \pm 0,23$ & $5,54 \pm 0,33$ & $4,53 \pm 0,18$ & $121,24 \pm 6,01$ \\
\hline Z2-TP & $6,50 \pm 0,27$ & $26,00 \pm 1,09$ & 2,8 & $9,59 \pm 0,84$ & $4,35 \pm 0,15$ & $6,70 \pm 0,27$ & $129,68 \pm 12,46$ \\
\hline Z3-TP & $7,14 \pm 0,26$ & $28,56 \pm 1,05$ & 2,95 & $12,11 \pm 0,84$ & $5,30 \pm 0,33$ & $4,50 \pm 0,35$ & $155,62 \pm 15,41$ \\
\hline Z1-MM & $13,24 \pm 0,8$ & $52,94 \pm 3,39$ & 3,31 & $10,77 \pm 0,88$ & $6,59 \pm 0,56$ & $8,18 \pm 0,52$ & $133,52 \pm 14,36$ \\
\hline Z2-MM & $13,72 \pm 0,21$ & $54,90 \pm 0,84$ & 3,31 & $10,15 \pm 0,20$ & $6,36 \pm 0,48$ & $7,07 \pm 0,63$ & $141,28 \pm 6,70$ \\
\hline Z3-MM & $13,75 \pm 0,01$ & $54,99 \pm 0,04$ & 3,34 & $9,20 \pm 0,37$ & $6,82 \pm 0,51$ & $7,05 \pm 0,40$ & $127,16 \pm 13,27$ \\
\hline Z1-TA & $9,63 \pm 0,61$ & $38,54 \pm 2,45$ & 3,15 & $10,47 \pm 0,87$ & $8,18 \pm 0,10$ & $6,41 \pm 0,55$ & $120,51 \pm 10,90$ \\
\hline Z2-TA & $9,48 \pm 0,04$ & $37,92 \pm 0,15$ & 3,08 & $9,66 \pm 0,33$ & $7,27 \pm 0,59$ & $7,03 \pm 0,48$ & $140,65 \pm 13,19$ \\
\hline Z3-TA & $10,69 \pm 0,06$ & $42,75 \pm 0,24$ & 3,14 & $10,46 \pm 0,76$ & $7,67 \pm 0,69$ & $7,23 \pm 0,55$ & $167,41 \pm 9,50$ \\
\hline
\end{tabular}

"Z: sampling zone (Z1: Maristes, Z2: Gueule Tapée, Z3: HLM); Drinks (TP, TA and MM).

\subsubsection{Chips}

The moisture and ash content of chips samples varied slightly according to sampling area but noticeably according to brand. Value ranges were $2.19 \pm 0.03-5.58 \pm 0.07 \%$ for moisture and $2.02 \pm 0.02-4.53 \pm 0.05 \%$ for ash. The macronutrients in chips were proteins $(5.95 \pm 0.10-10.70 \pm$ $0.05 \%)$, fat $(19.86 \pm 0.65-35.94 \pm 0.01 \%)$, carbohydrates $(47.43 \pm 0.44-64.65 \pm 0.78 \%)$ and dietary fiber $(1.55 \pm 0.10-$ $2.13 \pm 0.23 \%)$. The carbohydrates were found with the highest levels followed by fat and proteins. A variation in protein content of two brands according to the sampling area was noticed (Table 2). From values recorded in this study, it is noticeable that chips are poor sources of dietary fiber. Chips samples analyzed are highly energetic with energy values varying from $462.15 \pm 1.95$ to $570.45 \pm 3.21 \mathrm{kcal} / 100 \mathrm{~g}$. Two brands showed relatively similar energy values while that of the third brand was different. A slight variation according to sampling area was also registered. The main minerals in chips were sodium and potassium with levels of $580.04 \pm 23.98$ to $692.97 \pm 40.78 \mathrm{mg} / 100 \mathrm{~g}$ for sodium and $159.84 \pm 6.86$ to $318.57 \pm 1.09 \mathrm{mg} / 100 \mathrm{~g}$ for potassium. Variations in sodium content were slight according to sampling area and brand, whereas for potassium values were different from one brand to another and between sampling sites. 
Table 2. Chips samples analysis results.

\begin{tabular}{llllllllll}
\hline Code $^{*}$ & $\begin{array}{l}\text { Moisture } \\
(\mathbf{\%})\end{array}$ & $\begin{array}{l}\text { Fat content } \\
(\mathbf{\%})\end{array}$ & $\begin{array}{l}\text { Proteins } \\
\mathbf{( \% )}\end{array}$ & $\begin{array}{l}\text { Ashes } \\
\mathbf{( \% )}\end{array}$ & $\begin{array}{l}\text { Dietary } \\
\text { fibers (\%) }\end{array}$ & $\begin{array}{l}\text { carbohydrates } \\
\mathbf{( \% )}\end{array}$ & $\begin{array}{l}\text { Energy value } \\
\text { (kcal/100g) }\end{array}$ & $\begin{array}{l}\text { Sodium } \\
(\mathbf{m g} / \mathbf{1 0 0 g})\end{array}$ & $\begin{array}{l}\text { Potassium } \\
(\mathbf{m g} / \mathbf{1 0 0 g})\end{array}$ \\
\hline Z1-BG & $5,44 \pm 021$ & $24,37 \pm 2,25$ & $8,16 \pm 0,11$ & $2,77 \pm 0,06$ & $1,55 \pm 0,10$ & $57,71 \pm 2,32$ & $482,78 \pm 7,57$ & $667,38 \pm 16,84$ & $264,26 \pm 22,62$ \\
Z2-BG & $4,73 \pm 0,32$ & $23,27 \pm 0,77$ & $8,33 \pm 0,14$ & $2,02 \pm 0,02$ & $1,60 \pm 0,14$ & $60,06 \pm 1,36$ & $482,93 \pm 2,19$ & $639,34 \pm 27,45$ & $159,84 \pm 6,86$ \\
Z3-BG & $5,58 \pm 0,07$ & $21,07 \pm 0,30$ & $8,55 \pm 0,11$ & $2,11 \pm 0,14$ & $1,55 \pm 0,16$ & $61,13 \pm 0,38$ & $468,40 \pm 1,87$ & $580,04 \pm 23,98$ & $244,20 \pm 23,66$ \\
Z1-SD & $3,05 \pm 0,35$ & $20,25 \pm 0,39$ & $7,64 \pm 0,14$ & $2,74 \pm 0,23$ & $2,08 \pm 0,08$ & $64,25 \pm 0,16$ & $469,75 \pm 2,97$ & $689,43 \pm 26,62$ & $172,44 \pm 6,75$ \\
Z2-SD & $3,10 \pm 0,05$ & $21,88 \pm 1,52$ & $5,95 \pm 0,10$ & $2,29 \pm 0,04$ & $2,13 \pm 0,23$ & $64,65 \pm 0,78$ & $462,15 \pm 1,95$ & $647,08 \pm 63,91$ & $204,30 \pm 7,95$ \\
Z3-SD & $4,55 \pm 0,11$ & $19,86 \pm 0,65$ & $8,49 \pm 0,02$ & $2,33 \pm 0,35$ & $2,10 \pm 0,18$ & $62,49 \pm 0,54$ & $464,27 \pm 3,07$ & $692,97 \pm 40,78$ & $270,30 \pm 7,95$ \\
Z1-CH & $2,19 \pm 0,03$ & $35,94 \pm 0,01$ & $8,22 \pm 0,08$ & $4,53 \pm 0,05$ & $1,76 \pm 0,36$ & $47,43 \pm 0,44$ & $546,06 \pm 0,80$ & $646,79 \pm 48,69$ & $259,75 \pm 6,60$ \\
Z2-CH & $2,74 \pm 0,36$ & $31,29 \pm 0,34$ & $10,70 \pm 0,05$ & $4,53 \pm 0,04$ & $1,77 \pm 0,18$ & $48,97 \pm 0,56$ & $520,30 \pm 2,82$ & $630,01 \pm 47,40$ & $298,40 \pm 5,25$ \\
Z3-CH & $3,13 \pm 0,08$ & $33,60 \pm 0,10$ & $9,15 \pm 0,03$ & $4,40 \pm 0,20$ & $1,77 \pm 0,18$ & $47,95 \pm 0,40$ & $570,45 \pm 3,21$ & $566,85 \pm 18,32$ & $318,57 \pm 11,09$ \\
\hline
\end{tabular}

"Z: sampling zone (Z1: Maristes, Z2: Gueule Tapée, Z3: HLM); Chips (BG, SD and CH).

\section{Discussion}

\subsection{Survey}

The survey result revealed a widespread consumption of water-based flavoured drinks by Senegalese school-age children (88\%). In fact, snacking, also described as eating inbetween meals, is prevalent among children in many parts of the world. According to a survey performed in $2004,85 \%$ of US children aged 8-13 years declared regular consumption of soft drinks [21]. In Australia, almost half (46.7\%) of children aged 2-18 years drink sweetened beverages with an average consumption of $217 \mathrm{~mL}$ per day [22]. In China, in a sample of more than 53,000 children and adolescents aged 6-17 years, in 2013, 66.6\% of participants consumed sugar sweetened beverages [23].

The consumption of potato or maize chips was declared by $68 \%$ of school-age children. This result was similar to that reported by Iftikhar et $a l$. in a cross sectional study conducted in private schools of Karachi (Pakistan) with $76 \%$ of children consuming potato chips [24]. According to Wang et al., nearly all Chinese children (about 96\%) reported consuming snacks during at least one snacking period on any given day [25].

This high rate of snacking could be related to many factors among which the availability of soft drinks in the home and school and their affordability, the soft drink consumption patterns of parents and friends, the television viewing and the beverage taste preferences. Several studies reported a strong association between these factors and soft drink/chips consumption by children [26, 27].

The survey results evidences a high rate of sugar sweetened beverages and chips consumption which can result in many health problems such overweight and obesity, caries and enamel erosion, short sleep duration, hyperactivity, increased blood pressure and non-alcoholic fatty liver disease. In fact, sugar sweetened beverages are the richest foods in added sugars [28, 29].

\subsection{Drinks}

The carbohydrates were the main components of soft drinks after water. The total sugar contents ranged between $6.50 \pm 0.27$ and $13.75 \pm 0.01 \%$ and the energy values were between $26.00 \pm 1.09$ and $54.99 \pm 0.04 \mathrm{kcal} / 100 \mathrm{~g}$. Except for one brand, values of sugar contents complied with the limits set by the Codex alimentarius which are 6.8 to $13.3 \%$ and 8.3 to $12 \%$ for carbonated and non-carbonated soft drinks, respectively [30]. The exceeding of the sugar content limits could be explained by the type of beverages which are sugarsweetened and obtained by adding sugar and fruit juice during the manufacturing process. The samples with low percentages of sugar were those with no addition of fruit juice.

The carbohydrate contents measured in samples during this study were, in general, close to the values reported on the packaging by manufacturers which ranged between 7.2 to $15.5 \%$. Also, they were similar to that registered for fruit drinks in France $(8.8 \pm 2.3 \%)$ by Catteau et al. [31] and for carbonated drinks in Saudi Arabia (12.8 $\pm 0.99 \%)$ by Idriss et al. [32]. However some samples from a brand exhibited high carbohydrate levels. These levels were very high when compared with that of commonly known soft drinks such as Coca-Cola (8.5-11.1 g/100mL) or Sprite $(8.2-10.9 \mathrm{~g} / 100 \mathrm{~mL})$ [33].

Even if the samples have different sugar contents, the sweet taste was approximately the same suggesting that the sweetening characteristics of the soft drinks might be due to the addition of the same additives. In fact, several food additives (5-16) with several roles were mentioned on the packaging. The high content of sugar and the large number of food additives in a single product raises real concerns about negative health risks (dental caries, overweight, obesity, hyperactivity...). For example, food additive such as synthetic artificial food colors (AFCs) added to fruit juice to make them look bright and appealing to young children have been associated with children's behaviour with a role in exacerbating attention, deficit or hyperactivity disorder in children [34].

As the caloric components of the soft drinks are basically sugars, their energy values were calculated based on the results of the corresponding carbohydrate contents. Different energy values, ranging from 27.15 to $64.00 \mathrm{kcal} / 100 \mathrm{~mL}$ were recorded according to the brand; however they were relatively close for a brand when samples were collected from different areas. Values registered were, generally, in accordance with the labelling.

The $\mathrm{pH}$ values of the soft drinks varying between 2.79 and 3.34 revealed the acidic characteristic of these beverages. 
These values were within the Codex alimentarius standards which are 2.5 to 3.5 for carbonated soft drinks and 3 to 3.7 for non-carbonated soft drinks [30]. The low $\mathrm{pH}$ values of some samples is due to the presence of carbonic acid in these drinks. The acidic value of soft drinks should be carefully monitored as acidic $\mathrm{pH}$ could lead to dental erosion [31].

The values of mineral contents varied between $4.35 \pm 0.15$ $\mathrm{mg} / 100 \mathrm{~g}$ for sodium to $167.41 \pm 9.50 \mathrm{mg} / 100 \mathrm{~g}$ for calcium. A slight difference in mineral contents according to brand and sampling area was registered. The calcium contents of the drinks, ranging between 102.51 to $167.41 \mathrm{mg} / 100 \mathrm{~mL}$, exceeded at least five times the limits of 3 to $22 \mathrm{mg} / 100 \mathrm{~mL}$ set by the Codex alimentarius [30]. This high content could be due to the raw material used during the manufacturing process (sugar pre-bleached with lime, fruit juice with high calcium content...). Although, calcium is playing a great role in growth and development of children, its excessive intake can cause an upset stomach, abdominal pain, constipation and interfere with the absorption of iron and zinc which could lead to detrimental effects on blood parameters [35].

\subsection{Chips}

The results of moisture content in chips revealed a slight variation according to the sampling area but a noticeable difference between brands. These differences could be due to the raw material used in the manufacturing process of chips. Chips with high moisture content were made from maize whereas those with low moisture content were made from potatoes. Since starch has a high water retention capacity, the high moisture content of some chips samples could be related to the different amount of starch in potatoes and cereals [36].

The fat content of chips ranged between $19.86 \pm 0.65-$ $35.94 \pm 0.01 \%$ with a brand showing a noticeable difference from the others. Chips of this brand were potato-based whereas chips of the other brands were corn-based. The higher fat content of potato-based could be attributed to the high oil retention capacity of the raw potato material. Also the use of thin-cut chips can result in a higher fat content of chips. The greater surface area to volume ratio from thin cut or crinkle cut chips results in a proportionally larger absorption of fat [37].

The results obtained in this study were relatively similar to that reported by Albuquerque et al. [40] in Portugal (20-42\%) but higher than that found by Morley-John et al. [39] in New Zealand (5-20\%). Frying temperature also affects the fat content of the chips. Lower temperatures require longer frying times and the lack of crust formation on the chip surface results in more fat being absorbed [40].

Controlling the amount of moisture and fat in snack foods is an important parameter for process operators as they can affect quality and consistency, as well as the taste, appearance, stability and shelf life. Having too much moisture can affect the crunch by making the item taste stale or even worse contributing to bacteria/mold growth. Too much oil can make products greasy and higher in fat percentages. Additionally, variation and excess moisture and oil in chips can result in discoloration and out of specification of product [37].

The chips contents of protein ranged between $5.95 \pm 0.10$ to $10.70 \pm 0.05 \%$ and were relatively close except for two samples of different brands whose values were little far from the average content. The variations of protein content of samples of a brand result, probably, from the manufacturing process where preparations formulas were not respected.

The chips samples exhibited low levels of dietary fiber probably due to the naturally low content of this compound in the basic components of chips. The carbohydrates content was varying from 41.6 to $64.65 \%$. The highest levels were found in chips made of maize. This could be due to the fact that, the corn which is the basic ingredient of those chips contains more carbohydrates $(74.6 \%)$ than potato $(20.5 \%)$ which is the basic material of the other chips [41]. The energy values $(462.15-570.45 \mathrm{kcal} / 100 \mathrm{~g})$ of the chips were not constant for the same brand. This could be explained by the fact that the energy value is calculated from the protein, fat and carbohydrate contents of the product which were also not constant from one product to another. All the chips studied were very calorific meaning that their regular consumption in addition to meals consumed at home might raise overweight issues in children. Therefore, limiting the frequency of chips consumption during the day remains a necessity.

The chips selected in this study were, in general, weekly mineralized with ash contents ranging between 2.02 and $4.53 \%$. The sodium contents were comprised between 566.85 and $692.97 \mathrm{mg} / 100 \mathrm{~g}(0.56$ and $0.69 \%)$ with maize chips showing lower values than the potato ones. In their study in Portugal, Albuquerque et al. observed that most of the potato crisps analyzed have considerable amounts of salt and about $50 \%$ of the analyzed products contain more than $1 \mathrm{~g}$ of salt/100 $\mathrm{g}$ [38]. The difference in sodium content could be due to the fact that maize chips contain more sugar $(2.6 \%)$ and its salting is reduced in comparison to potatoes chips $(0.5 \%$ of sugar). The results of this study were similar to that reported in France $(0.65 \pm 0.15 \%)$ but lower than levels of 0.12 to $2.77 \%$ found in Portugal [ 38 , 42]. Variations in sodium content might be due to a noncontrolled addition of salt by some food industries.

\section{Conclusion}

Snacking with sugar-sweetened beverages and chips is commonly practiced by Senegalese school-age children. The experimental analyzes carried out on samples of soft drinks and chips of three brands each showed that sweetened drinks are essentially composed of water and sugars whereas the main components of chips were fat, carbohydrates and proteins. Some of these components exhibited high values that can lead to unhealthy risks. It appears legitimate, given the increasing consumption of these drinks and chips, to be concerned about the quality of these products. Mores studies are needed to document the complete range of products consumed by children in the country and estimate their impact on children's health. This study is leading the path on 
the matter. The results will help orient the strategies to put into effect in order to inform children and their parents on the best diets to adopt for a healthy and quality life.

\section{Acknowledgements}

Gratitude is expressed the "Institut de Technologie Alimentaire (ITA)" of the Senegalese Ministry of industrial development for its technical support.

\section{References}

[1] Smith, T. (2010). Malnutrition: causes and consequences. Clin Med, 10 (6): 624-627.

[2] Astley, S., Finglas, P. (2016). Nutrition and health, in: Simthers, G., Trinetta, V., Knoerzer, K (Eds.), Reference module in food science. Elsevier, Rio de Janeiro, p1-7. doi: 10.1016/B978-0-08-100596-5.03425-9.

[3] Khan, A., Khan, S., Zia-ul-Islam, S., Tauqeer, A. M., Riffat, Khan, M. (2017). Causes, sign and symptoms of malnutrition among the children. J Nutr Hum Health, 1 (1): 24-27.

[4] Kruizenga, H., Beijer, S., Huisman-de Waal, G., JonkersSchuitema, C., Klos, M., Remijnse-Meester, W., Thijs, A., Tieland, M., Ben Witteman, B. (2017). Guideline on malnutrition: recognizing, diagnosing and treating malnutrition in adults. Translation: Alison Fisher, Dutch Malnutrition Steering Group.

[5] WHO. (2020). Facts on malnutrition. Retrieved October $31^{\text {st }}$, 2020, from https://www.who.int/news-room/factsheets/detail/malnutrition.

[6] MCU (2017) (Malnutrition Control Unit). Nutritional SMART Survey (2014). Report of the National Agency for Statistics and Demography of Senegal (ANSD).

[7] Barry, M. P., Corvalan, C., Grummer-Strawn, L. (2020). Dynamics of the double burden of malnutrition and the changing nutrition reality. Lancet. Jan 4; 395 (10217): 65-74.

[8] Faye, J., Diop, M., Gati Ouonkoye, R. et al. (2011). Prévalence de l'obésité de l'enfant et de l'adolescent en milieu scolaire à Dakar. Bull. Soc. Pathol. Exot. 104: 49-52. doi: 10.1007/s13149-010-0101-9.

[9] Dey, A. (2018). Global consequence of malnutrition and its preventive methodologies. Int J Food Sci Nutr, 3 (6): 263-267.

[10] Saunders, J. and Smith T. (2010). Malnutrition: causes and consequences. Clin Med, 10 (6): 624-7. doi: 10.7861/clinmedicine.10-6-624.

[11] Wells, J. C., Sawaya, A. L., Wibaek, R., Mwangome, M., Poullas, M. S., Yajnik, C. S., Demaio, A. (2020). The double burden of malnutrition: aetiological pathways and consequences for health. Lancet, 395 (10217): 75-88. doi: 10.1016/S0140-6736(19)32472-9.

[12] Baba, A. (2017). Les chips et les boissons gazeuses n'ont aucune valeur nutritive pour les enfants. Retrieved October $18^{\text {th }}, 2020$, from https://laviesenegalaise.com/les-chips-et-lesboissons-gazeuses-nont-aucune-valeur-nutritive-pour-lesenfants/.
[13] Marrubini, G., Papetti, A., Genorini, E., Ulrici, A. (2017). Determination of the sugar content in commercial plant milks by near infrared spectroscopy and luff-schoorl total glucose titration. Food Analytical Methods 10: 1556-1567. doi: 10.1007/s12161-016-0713-1.

[14] Charrondiere, U. R., Chevassus-Agnes, S., Marroni, S., Burlingame, B. (2004). Impact of different macronutrient definitions and energy conversion factors on energy supply estimations. Journal of Food Composition and Analysis 17: 339-360. doi: 10.1016/j.jfca.2004.03.011.

[15] Official Methods of Analysis (2005), $18^{\text {th }}$ ed., AOAC INTERNATIONAL, Gaithersburg, MD, USA, Method 968.08.

[16] Official Methods of Analysis (2005), 18th ed., AOAC INTERNATIONAL, Gaithersburg, MD, USA, Methods 925.10-945.15.

[17] Official Methods of Analysis (2005), 18th ed., AOAC INTERNATIONAL, Gaithersburg, MD, USA, Method 923.03.

[18] Official Methods of Analysis (2005), 18th ed., AOAC INTERNATIONAL, Gaithersburg, MD, USA, Method 2001.11 .

[19] Official Methods of Analysis (2005), 18th ed., AOAC INTERNATIONAL, Gaithersburg, MD, USA, Method 2003.06.

[20] Official Methods of Analysis (2005), 18th ed., AOAC INTERNATIONAL, Gaithersburg, MD, USA, Method 978.10.

[21] Grimm, G. C., Harnack, L., Story, M. (2004). Factors associated with soft drink consumption in school-aged children. J Am Diet Assoc.; 104: 1244-1249.

[22] Brand-Miller, J. C., Barclay, A. W. (2017). Declining consumption of added sugars and sugar-sweetened beverages in Australia: a challenge for obesity prevention. Am J Clin Nutr. Apr; 105 (4): 854-63.

[23] Gui, Z. H., Zhu, Y. N., Cai, L., Sun, F. H., Ma, Y. H., Jing, J., et al. (2017). Sugar-sweetened beverage consumption and risks of obesity and hypertension in Chinese children and adolescents: a national cross-sectional analysis. Nutrients, 9 (12): 1302 .

[24] Iftikhar, A., Zafar, M., Kalar, M. U. (2012). The relationship between snacking habits and dental caries in school children. International Journal of Collaborative Research on Internal Medicine \& Public Health, 4 (12): 1943-51.

[25] Wang, D., van der Horst, K., Jacquier, E. F., Afeiche, M. C., Eldridge, A. L. (2018). Snacking patterns in children: A comparison between Australia, China, Mexico, and the US. Nutrients, 10 (2): 198. doi: 10.3390/nu10020198.

[26] Story, M., Hayes, M., Kalina, B. (1996). Availability of foods in high schools: Is there cause for concern. J Am Diet Assoc., 96: 123-126.

[27] Hitchings, E., Moynihan, J. (1998). The relationship between television food advertisements recalled and actual foods consumed by children. J Hum Nutr Diet., 1: 511-517.

[28] Schwimmer, J. B., Ugalde-Nicalo, P., Welsh, J. A., Angeles, J. E., Cordero, M., Harlow, K. E., et al. (2019). Effect of a low free sugar diet vs usual diet on nonalcoholic fatty liver disease in adolescent boys: a randomized clinical trial. JAMA, 321 (3): 256-65. 
[29] Nier, A., Brandt, A., Conzelmann, I. B., Ozel, Y., Bergheim, I. (2018). Non-alcoholic fatty liver disease in overweight children: role of fructose intake and dietary pattern. Nutrients; 10 (9): 1-18.

[30] Commission du Codex Alimentarius. (2005). Norme générale Codex pour les jus et nectars de fruits. Rome: Organisation Mondiale de la Santé: Organisation des Nations Unies pour l'Alimentation et l'Agriculture.

[31] Catteau, C., Trentesaux, T., Delfosse, C., Rousset, M. M. (2012). Impact des jus de fruits et des boissons fruitées sur la santé de l'enfant et de l'adolescent: le point de vue du chirurgien-dentiste. Archives de Pédiatrie, 19 (2): 118-124.

[32] Idris, A. M., Vani, N. V., Almutari, D. A., Jafar, M. A., Boreak, N. (2016). Analysis of sugars and pH in commercially available soft drinks in Saudi Arabia with a brief review on their dental implictions. J Int Soc Prevent Communit Dent, 6, Suppl S3: 192-6.

[33] Ventura, E. E., Davis, J. N., Goran, M. I. (2011). Sugar content of popular sweetened beverages based on objective laboratory analysis: Focus on fructose content. Obesity, 19: 868-874. doi: 10.1038/oby.2010.255.

[34] Trasande, L., Shaffer, R. M., Sathyanarayana, S. (2018). Food additives and child health. Pediatrics, 142 (2), e20181410. doi: 10.1542/peds.2018-1410.

[35] Tittikpina, N. K., Issa, A. B., Yerima, M., Dermane, A., Dossim, S., Salou, M., Bakoma, B., Diallo, A., Potchoo, Y., Diop Y. M. (2019). Aging and nutrition: theories, consequences. Current Pharmacology Reports, 5 (4): 232-243. doi: 10.1007/s40495-019-00185-6.
[36] Cortez, N., Joo, D. P., Roberto, C. O. F., Judite, L. G., Maria, M. E. V. (2014). Physicochemical and sensory characteristics of snack made with minced Nile tilapia. Food Sci. Technol, Campinas, 34 (3): 591-596.

[37] Goni, I., Bravo, L., Larrauri, J. A., Saura Clixto, F. (1997). Resistant starch in potatoes deep-fried in olive oil. Food Chem, (2): 269-72.

[38] Albuquerque, T. G., Sanches-Silva, A., Santos, L., et al. (2012). An update on potato crisps contents of moisture, fat, salt and fatty acids (including trans-fatty acids) with special emphasis on new oils/fats used for frying. Int J Food Sci Nutr., 63: 713-717. doi: 10.3109/09637486.2011.644768.

[39] Morley-John, J., Swinburn, B. A., Metcalf, P. A., Raza, F. (2002). Fat content of chips, quality of frying fat and deepfrying practices in New Zealand fast food outlets. Aust N Z J Public Health, 26: 101-7.

[40] Ufheil, G., Escher, F. (1996). Dynamics of oil uptake during deep-fat frying of potato slices. Lebensmittel-Wissenschaft Technologie, 29 (7): 640-4.

[41] Bonierbale, M., Zapata, G. B., zum Felde, T., Sosa, P. (2010). Composition nutritionnelle des pommes de terre. Cahiers de nutrition et de diététique, 45 (6S1): S28-S36. doi: 10.1016/S0007-9960(10)70005-5.

[42] ANSES. (2013). Etude de l'évolution de la composition nutritionnelle de la catégorie des chips entre 2009 et 2011. Retrieved October $\quad 7^{\text {th }}, \quad 2020$ from https://www.oqali.fr/content/download/3302/32375/file/Oqali _Rapport_evolution_chips_2013.pdf. 